\title{
An examination of value-added and variable cost trends across Canadian forest regions and sectors
}

\author{
by Van Lantz ${ }^{1}$
}

\begin{abstract}
Value-added forestry has received much attention in the past few decades as a means of generating more output value for a given timber input. The growth in value-added production in the forest industry is directly affected by changing forest output/input prices, technology, investment strategies, government policies, and a host of other factors. Since many of these factors are unique to each forest region and sector in Canada, it is expected that one would observe a number of different value-added and variable cost trends over time. The purpose of this paper is to examine value-added and variable cost trends in five regions and three sectors of the Canadian forest industry over the 1970-95 period in order to shed light on those that are the most promising. A seemingly unrelated regressions technique is employed to the data set and findings reveal that a number of sectors and regions have exhibited favourable value-added/variable cost trends. Others, however, have not. Suggestions are made as to where future industry investments and government policies might be directed to aid in the development of value-added.
\end{abstract}

Key words: Canadian forest industry, value-added, variable cost, profit, regional analysis, seemingly unrelated regressions

La foresterie à valeur ajoutée a bénéficié de beaucoup d'attention au cours des dernières décennies en tant que moyen de générer des retombées de plus grande valeur à partir d'une source donnée de bois. La croissance de la production à valeur ajoutée au sein de l'industrie forestière est directement affectée par les prix fluctuants de la ressource forestière et des produits transformés, par la technologie, par les stratégies d'investissement, par les politiques gouvernementales et par plusieurs autres facteurs. Compte tenu que plusieurs de ces facteurs sont uniques à chaque région forestière et à chaque secteur forestier du Canada, on pourrait s'attendre à observer certaines tendances différentes en matière de valeur ajoutée et de coûts variables en fonction du temps. L'objectif de cet exposé est d'examiner les tendances en matière de valeur ajoutée et de coûts variables dans cinq régions et trois secteurs de l'industrie forestière canadienne au cours de la période de 1970 à 1995 de façon à identifier celles qui sont les plus prometteuses. Une technique de régression sans rapport apparent est utilisée sur l'ensemble des données et les constatations indiquent que certains secteurs et certaines régions ont connu des tendances favorables en matière de valeur ajoutée et de coûts variables. Cependant, ce n'est pas le cas pour d'autres. Des suggestions sont faites afin d'indiquer où les investissements futurs de l'industrie et les politiques gouvernementales pourraient être dirigés afin d'aider au développement des produits à valeur ajoutée.

Mots-clés : industrie forestière canadienne, valeur ajoutée, coût variable, profit, analyse régionale, régressions sans rapport apparent

\section{Introduction}

Most sectors in the Canadian forest industry are currently experiencing favourable market conditions, especially when compared to the historic market downturns that occurred in the early 1980s and again in the early 1990s. These historic downturns created a "profits squeeze" that forced most sectors in the industry to re-think the way they produced their products. The strategies that emerged out of this re-thinking included: (i) new technology adoption to reduce production costs; and (ii) direct investment into higher valued products (see Barbour and Kellogg 1990, Meil 1990, Schuler and Meil 1990, Cohen 1992, Baldwin 1998).

In order to promote the new technology and higher value strategies that emerged in the early 1980s, the federal and provincial governments began establishing multi-level capacity, modernization, and R\&D policies for targeted wood product manufacturing sectors (Shaw 1994, ACOA 1998). Since this time, a number of forest sectors have experienced increases in efficiency, productivity, and overall competitiveness (see, for instance, Frank et al. 1990, Ghebremichael et al. 1990, Brunet 1993, Abt et al. 1994, Bernstein 1994, Hseu and Buongiorno 1994, Lantz 1995, Kant and Nautiyal 1997, Hailu and Veeman 2003). It can be reasonably argued that the strategies introduced and facilitated in the early 1980s are partly responsible

\footnotetext{
${ }^{1}$ Faculty of Forestry \& Environmental Management, and Department of Economics, University of New Brunswick, P.O. Box 44555, Fredericton, New Brunswick E3B 5A3. E-mail: vlantz@unb.ca
}

for the increased profit levels that many forest sectors have been experiencing since the mid 1990 s. $^{2}$

One way of measuring profitability in a forest sector is through an evaluation of valueadded. Value-added is a simple unencumbered profit measure of converting raw materials into products (Meil 1990). It consists of subtracting the cost of materials/supplies and energy from the shipment value of out-

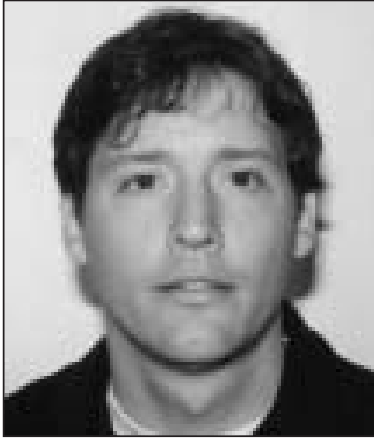

Van Lantz put. ${ }^{3}$ Thus, value-added will only increase in a sector if the rate of growth of shipment value is greater than the combined rate of growth in materials/supplies and energy costs.

Value-added growth, however, can be indirectly affected by a number of factors. For instance, even if value-added increases in a sector over time, it may be that this growth is outpaced by variable labour and/or capital cost growth. As these variable costs approach value-added levels, profits will decrease and further value-added growth will prove impossible

\footnotetext{
${ }^{2}$ Other factors that have contributed to increased profits since the mid-1990s include a mix of favourable exchange rates, input/output prices, trade agreements, and an overall healthy domestic and US economy.

${ }^{3}$ Alternatively, value-added can be thought of as a simple measure of surplus over a restricted input domain that does not include either labour or capital costs.
} 
without significant industrial re-structuring (Meil 1990). Such situations have occurred periodically throughout the past thirty years as mechanization investments have occurred (through substituting capital for labour) in attempts to reduce production costs in the long run (see, for instance, Duke and Huffstutler 1977, Bernstein 1994, Sedjo 1997).

The changes in input costs, shipment values, and investment strategies are unique to each forest sector and region throughout Canada. This uniqueness creates variation in the efficiency, productivity, and overall competitiveness of particular forest regions and sectors in Canada, as emphasized in studies such as Ghebremichael et al. (1990), Abt et al. (1994), Bernstein (1994), Lantz (1995), and Hailu and Veeman (2003). However, there has been little investigation into the cumulative impact that these factors have had on value-added. The only such study found in an extensive review of the literature was that of Meil (1990), who analyzed the value-added and variable cost lumber trends in the British Columbia coast/interior, Ontario, and Quebec regions over the 1970-84 period. He found that both value-added and variable cost variables trended downward over this period in each lumber region, and that the value-added trend exhibited a steeper slope than the variable cost trend. Projecting these trends into the future, Meil (1990) found that softwood lumber mills had already or were quickly approaching a convergence of value-added and variable costs, and thus a dramatic change in production structure was needed in this sector. There have not, however, been any studies that extend this analysis using more recent data, or that investigate other regions and/or sectors of the industry. Additionally, Meil (1990) did not include capital costs in his analysis, as he treated this as a fixed cost within the short time period considered. Therefore, a more broad-based examination of long-run regional and sectoral value-added and variable cost trends is needed to assess the potential of further value-added development within this industry.

The objective of this study is to evaluate the trends in valueadded and variable costs across five regions and three sectors of the Canadian forest industry. The five geographic forest regions include the Atlantic region, Quebec, Ontario, the Prairie region, and British Columbia, while the three sectors include logging, wood products, and paper \& allied. The analysis to be presented will model each forest region/sector valueadded and variable cost time trend, and identify the sectors and regions that have exhibited the greatest value-added development. The results will be useful for industry members concerned about the prospects of sustained profit levels in the industry, and will provide some insight for policy-makers who are interested in initiating future value-added policies.

The remainder of this paper is organized as follows. The next section describes the value-added and variable cost trends analyzed in this study. The methodology of the study is defined and data sources are discussed in the following two sections. Then, a fifth section presents the results of the regression analysis and plots the point estimates of the valueadded and variable cost development trends for each forest sector and region. The last section discusses the possible implications of the findings and concludes.

\section{Methods}

Statistics Canada has developed standardized definitions and methods to analyze value-added and variable costs in forest industry sectors. When calculating value-added statistics, Statistics Canada subtracts the cost of materials/supplies and energy from the value of production output. This statistic, as mentioned previously, is one way to assess profit levels in the industry. The value-added (VA) measure can be defined as follows:

$$
\text { [1] VA= }\left(\begin{array}{l}
\text { Value of } \\
\text { Output }
\end{array}\right)-\left(\begin{array}{l}
\text { Costs of } \\
\text { Materials \& Supplies }
\end{array}\right)-\left(\begin{array}{l}
\text { Costs of } \\
\text { Energy }
\end{array}\right)
$$

The value-added variable defined in equation [1] can be compared to variable production costs over the long run in order to assess the total profit levels for a forest sector in any time period. ${ }^{4}$ Variable production costs in the forest industry have traditionally been defined as the expenditures on capital, labour, materials/supplies, and energy inputs. With the latter two cost components already included in the value-added measure, the variable cost (VC) function can be expressed as follows:

[2] $V C=\left(\begin{array}{l}\text { Costs of } \\ \text { Labour }\end{array}\right)+\left(\begin{array}{l}\text { Costs of } \\ \text { Capital }\end{array}\right)$

All sectors and regions of the forest industry exhibit varying value-added and variable cost values. Forest sector valueadded, for instance, increases significantly moving from a primary product-producing sector, such as logging, to a secondary manufacturing sector, such as wood furniture (Wilson et al. 1999). Additionally, regional differences in value-added may result from varying product prices and costs (resulting from different demand/supply conditions), and different production structures (Meil and Nautiyal 1988, Lantz 1995, Lantz In Press).

In order to investigate trends in value-added and variable costs, a generalized reduced-form equation is specified as follows:

$$
\text { [3] } V_{i j k t}=\alpha_{i j k}+\sum_{m=1}^{m} \beta_{i m} T^{m}+\varepsilon_{i j k t}
$$

where $V_{i j k t}$ represents the $i^{\text {th }}$ value $(i=[V A, V C])$ in region $j$ ( $j=$ [Atlantic, Quebec, Ontario, Prairies, British Columbia]), sector $k(k=[$ logging, wood, paper $\&$ allied $])$, and period $t$; $\alpha_{i j k}$ is an intercept term; $\beta_{i m}$ is the unknown vector of slope coefficients for the time effect vector $T^{m}$, where $m$ takes on the value of 1,2 , or 3 when a linear, quadratic, or cubic model is specified, respectively ${ }^{5}$; and $\epsilon_{i j k t}$ is the error term.

The sectors examined in this study include the logging, wood (lumber, shingle, veneer and plywood, sash, door and other millwork, wooden box, coffin and casket, and miscellaneous wood), and paper \& allied (pulp and paper, paper box, paper bag, and miscellaneous paper converter, asphalt roofing) sectors. Five Canadian regions are included in the analysis over the 1970-95 period. The regions include Atlantic Canada (Newfoundland, PEI, Nova Scotia, and New Brunswick), Quebec, Ontario, the Prairies (Manitoba, Saskatchewan, and Alberta), and British Columbia.

\footnotetext{
4 The total profit value defined here does not include tax, marketing, or other such additional costs.

${ }^{5}$ Higher order relationships were considered in the analysis presented below; however, they were not significant in any of the regressions.
} 
Table 1. Five-year real growth rates in regional logging, wood product, and paper \& allied sector value-added (VA) and variable costs (VC)

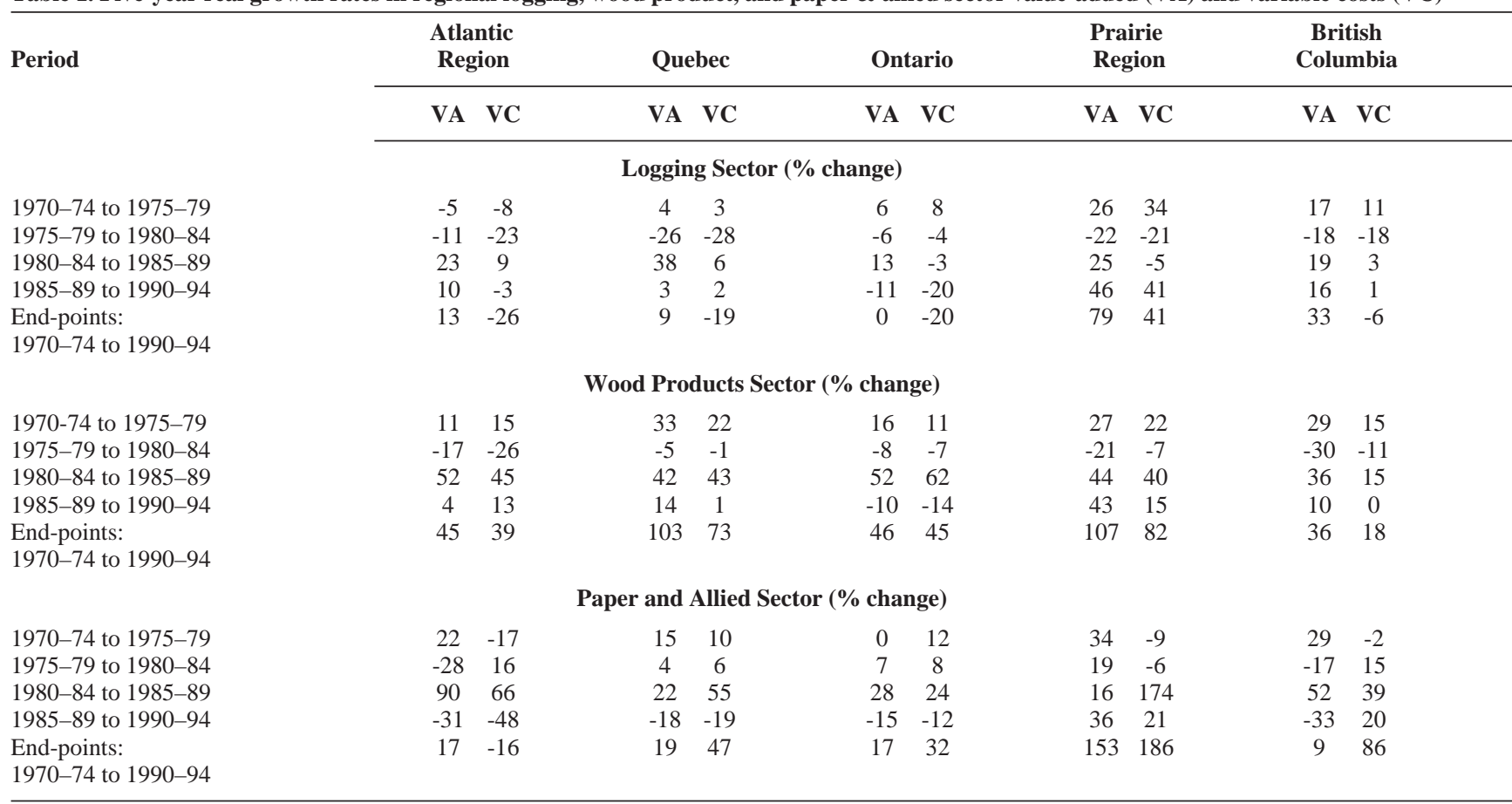

Equation [3] is estimated using the seemingly unrelated regression (SUR) technique. This technique, otherwise known as a three-stage least-squares estimation procedure, treats each region and sector as a separate regression equation, and estimates a set of sector-specific value-added or variable cost equations as a system wherein the error terms across equations are assumed contemporaneously correlated (see Greene 1993). In total, there are six SUR regressions estimated. This includes one value-added SUR estimation for each of the three forest sectors, and another three SUR estimations for their associated variable costs.

The assumption of correlated errors in each system is justified on grounds that exogenous events, such as forest product demand shocks, are expected to flow through Canadian forest sectors in a similar manner (since, in many cases, this industry is highly integrated). A likelihood ratio test of the diagonal covariance matrix confirms this conjecture by rejecting, via the statistic, the null hypothesis of zero correlation of the residuals in all SUR regressions (see Table 2). As such, the SUR estimation improves the accuracy of the estimates over standard ordinary least squares (OLS) estimates.

\section{Data and Descriptive Analysis}

The value-added, labour cost (wage expenditure), and energy cost (fuel and electricity expenditure) data were collected for the 1970-95 period from Statistics Canada (1970-95). The capital cost data were collected from NRCan (2004), and consists of annual capital and repair expenditures. All valueadded and variable cost data were converted to constant values (base year = 1992) using the Industrial Products Price Index (IPPI) found on Statistics Canada's CANSIM database, matrix 1870 (Statistics Canada 2001). ${ }^{6}$

6 The data set is restricted to the $1970-95$ period due to data availability limitations.
As mentioned previously, the data set consists of five regions and three sectors. The five regions were chosen in order to reasonably limit the variation in output levels between regions. More specifically, the three individual provinces of British Columbia, Ontario, and Quebec represent the largest shipment values of forest products of all provinces in Canada. Grouping the other provinces into Atlantic and Prairie regions increases their output levels toward these provinces. ${ }^{7}$ The three sectors were chosen because NRCan (2004) only provides capital and repair expenditures for the provincial logging, wood product, and paper \& allied sectors (for confidentiality reasons). As such, this limits the degree of focus on individual sectors.

A five-year period summary of real value-added and variable cost growth rates across five regions and three sectors of the Canadian forest industry is provided in Table 1 for the 1970-95 period. As revealed, the growth rates fluctuate widely from period to period for both value-added and variable costs. ${ }^{8}$ The growth rate extremes tend to have occurred in the paper $\&$ allied sector. More specifically, in this sector, the five-year value-added growth rates range from a high of $+90 \%$ for the 1980-84 to $1985-89$ periods in the Atlantic region, to a low of $-33 \%$ for the $1985-89$ to $1990-94$ periods in the British Columbia region. Likewise, variable costs range from a high of $+174 \%$ for the $1980-84$ to $1985-89$ period in the Prairie region, to a low of $-48 \%$ for the $1985-89$ to $1990-94$ period in the Atlantic region.

\footnotetext{
${ }^{7}$ Additionally, Statistics Canada (1970-95) provides incomplete value-added and/or variable cost data for some of the smaller provinces in the Atlantic and Prairie regions. This missing information is either omitted from the analysis (when data for a number of successive years are missing), or approximated (when only one or two year's data is missing). The omissions and approximations will limit the accuracy of the estimates for these regions.

${ }^{8}$ Recall that variable costs, as defined here, include only labour and capital costs (see Equation 2), and are exclusive of raw material and energy costs (since these last two components are included in value-added).
} 
Table 2. SUR regression results for Canadian regional forest sector value-added and variable cost trends ${ }^{\mathrm{a}, \mathrm{b}}$

\begin{tabular}{|c|c|c|c|c|c|c|}
\hline \multirow{2}{*}{$\begin{array}{l}\text { Regional } \\
\text { Coefficient } \\
\text { Estimates }\end{array}$} & \multicolumn{3}{|c|}{ Value-added } & \multicolumn{3}{|c|}{ Variable Costs } \\
\hline & Logging & Wood & Paper \& Allied & Logging & Wood & Paper \& Allied \\
\hline$C O N S T_{A T L}$ & $\begin{array}{l}285.730 * * * \\
(6.766)\end{array}$ & $\begin{array}{l}164.510 * * * \\
(4.693)\end{array}$ & $\begin{array}{l}454.240 * \\
(1.849)\end{array}$ & $\begin{array}{l}203.730 \text { **** } \\
(11.44)\end{array}$ & $\begin{array}{l}117.090 * * * \\
(5.795)\end{array}$ & $\begin{array}{l}986.210 * * * \\
(6.303)\end{array}$ \\
\hline$T_{A T L}$ & $\begin{array}{l}-6.974 \\
(0.525)\end{array}$ & $\begin{array}{l}10.198 \\
(0.924)\end{array}$ & $\begin{array}{l}78.888 \\
(1.111)\end{array}$ & $\begin{array}{l}-6.617 \\
(-1.181)\end{array}$ & $\begin{array}{l}6.472 \\
(1.018)\end{array}$ & $\begin{array}{l}-165.900 * * * \\
(-3.369)\end{array}$ \\
\hline$T_{A T L}^{2}$ & $\begin{array}{l}0.394 \\
(0.348)\end{array}$ & $\begin{array}{l}-0.882 \\
(-0.939)\end{array}$ & $\begin{array}{l}-6.714 \\
(-1.110)\end{array}$ & $\begin{array}{l}0.219 \\
(0.458)\end{array}$ & $\begin{array}{l}-0.644 \\
(-1.190)\end{array}$ & $\begin{array}{l}16.200 \text { **** } \\
(3.861)\end{array}$ \\
\hline$T_{A T L}^{3}$ & $\begin{array}{l}-0.002 \\
(-.055)\end{array}$ & $\begin{array}{l}0.028 \\
(1.261)\end{array}$ & $\begin{array}{l}0.183 \\
(1.244)\end{array}$ & $\begin{array}{l}0.003 \\
(0.234)\end{array}$ & $\begin{array}{l}0.020 \\
(1.574)\end{array}$ & $\begin{array}{l}-0.412 * * * \\
(-4.025)\end{array}$ \\
\hline$C O N S T_{Q U E}$ & $\begin{array}{l}636.330 * * * \\
(7.700)\end{array}$ & $\begin{array}{l}477.920 * * * \\
(2.810)\end{array}$ & $\begin{array}{l}1761.200 * * * \\
(4.149)\end{array}$ & $\begin{array}{l}440.390 * * * \\
(7.931)\end{array}$ & $\begin{array}{l}372.200 * * * \\
(4.995)\end{array}$ & $\begin{array}{l}1760.700 * * * \\
(6.026)\end{array}$ \\
\hline$T_{Q U E}$ & $\begin{array}{l}-19.715 \\
(-0.758)\end{array}$ & $\begin{array}{l}130.470 * * \\
(2.437)\end{array}$ & $\begin{array}{l}237.980 * \\
(1.781)\end{array}$ & $\begin{array}{l}-19.622 \\
(-1.123)\end{array}$ & $\begin{array}{l}40.653^{*} \\
(1.734)\end{array}$ & $\begin{array}{l}-146.610 \\
(-1.594)\end{array}$ \\
\hline$T_{Q U E}^{2}$ & $\begin{array}{l}1.166 \\
(0.526)\end{array}$ & $\begin{array}{l}-9.600 * * \\
(-2.105)\end{array}$ & $\begin{array}{l}-16.177 \\
(-1.421)\end{array}$ & $\begin{array}{l}1.637 \\
(1.099)\end{array}$ & $\begin{array}{l}-2.165 \\
(-1.084)\end{array}$ & $\begin{array}{l}21.079 * * * \\
(2.690)\end{array}$ \\
\hline$T^{3}{ }_{Q U E}$ & $\begin{array}{l}0.014 \\
(-0.264)\end{array}$ & $\begin{array}{l}0.268 * * \\
(2.410)\end{array}$ & $\begin{array}{l}0.383 \\
(1.380)\end{array}$ & $\begin{array}{l}-0.36 \\
(-0.987)\end{array}$ & $\begin{array}{l}0.059 \\
(1.227)\end{array}$ & $\begin{array}{l}-0.579 * * * \\
(-3.037)\end{array}$ \\
\hline$C O N S T_{O N T}$ & $\begin{array}{l}399.050 * * * \\
(12.25)\end{array}$ & $\begin{array}{l}606.590 * * * \\
(4.674)\end{array}$ & $\begin{array}{l}2228.300 * * * \\
(6.238)\end{array}$ & $\begin{array}{l}284.790 * * * \\
(11.22)\end{array}$ & $\begin{array}{l}458.360 \text { **** } \\
(5.121)\end{array}$ & $\begin{array}{l}1457.600 * * * \\
(7.981)\end{array}$ \\
\hline$T_{O N T}$ & $\begin{array}{l}4.898 \\
(0.477)\end{array}$ & $\begin{array}{l}33.467 \\
(0.819)\end{array}$ & $\begin{array}{l}19.988 \\
(0.1778)\end{array}$ & $\begin{array}{l}4.629 \\
(0.579)\end{array}$ & $\begin{array}{l}-11.590 \\
(-0.411)\end{array}$ & $\begin{array}{l}-10.786 \\
(-0.188)\end{array}$ \\
\hline$T^{2}{ }_{O N T}$ & $\begin{array}{l}-0.012 \\
(-0.014)\end{array}$ & $\begin{array}{l}-1.056 \\
(-0.303)\end{array}$ & $\begin{array}{l}2.361 \\
(0.2465)\end{array}$ & $\begin{array}{l}-0.18 \\
(-0.027)\end{array}$ & $\begin{array}{l}2.402 \\
(1.001)\end{array}$ & $\begin{array}{l}5.392 \\
(1.101)\end{array}$ \\
\hline$T^{3}{ }_{O N T}$ & $\begin{array}{l}-0.006 \\
(-0.295)\end{array}$ & $\begin{array}{l}0.027 \\
(0.322)\end{array}$ & $\begin{array}{l}-0.061 \\
(-0.264)\end{array}$ & $\begin{array}{l}-0.006 \\
(-0.376)\end{array}$ & $\begin{array}{l}-0.060 \\
(-1.032)\end{array}$ & $\begin{array}{l}-0.162 \\
(-1.362)\end{array}$ \\
\hline$C O N S T_{P R A}$ & $\begin{array}{l}50.506^{* * * *} \\
(3.36)\end{array}$ & $\begin{array}{l}190.020 * * * \\
(2.675)\end{array}$ & $\begin{array}{l}60.140 \\
(0.666)\end{array}$ & $\begin{array}{l}83.554 * * * \\
(3.491)\end{array}$ & $\begin{array}{l}160.720 * * * \\
(3.349)\end{array}$ & $\begin{array}{l}558.160 \text { *** } \\
(3.386)\end{array}$ \\
\hline$T_{P R A}$ & $\begin{array}{l}21.686 * * * \\
(4.687)\end{array}$ & $\begin{array}{l}71.991 * * * \\
(3.221)\end{array}$ & $\begin{array}{l}81.812 * * * \\
(2.879)\end{array}$ & $\begin{array}{l}-7.819 \\
(-1.038)\end{array}$ & $\begin{array}{l}31.636^{* * *} \\
(2.094)\end{array}$ & $\begin{array}{l}-142.680 * * * \\
(-2.750)\end{array}$ \\
\hline$T_{P R A}^{2}$ & $\begin{array}{l}-2.119 * * * \\
(-5.376)\end{array}$ & $\begin{array}{l}-7.006^{* * * *} \\
(-3.722)\end{array}$ & $\begin{array}{l}-7.831 * * * \\
(-3.234)\end{array}$ & $\begin{array}{l}0.697 \\
(1.087)\end{array}$ & $\begin{array}{l}-2.912 * * \\
(-2.263)\end{array}$ & $\begin{array}{l}13.711 * * * \\
(3.102)\end{array}$ \\
\hline$T_{P R A}^{3}$ & $\begin{array}{l}0.060 * * * \\
(6.344)\end{array}$ & $\begin{array}{l}0.214 * * * \\
(4.618)\end{array}$ & $\begin{array}{l}0.234 * * * \\
(3.970)\end{array}$ & $\begin{array}{l}-0.012 \\
(-0.744)\end{array}$ & $\begin{array}{l}0.090 * * * \\
(2.889)\end{array}$ & $-0.314 * * *$ \\
\hline$C O N S T_{B C}$ & $\begin{array}{l}1003.900 * * * \\
(4.496)\end{array}$ & $\begin{array}{l}1431.400 * * * \\
(2.814)\end{array}$ & $\begin{array}{l}1222.900 * * * \\
(2.667)\end{array}$ & $\begin{array}{l}625.740 * * * \\
(8.174)\end{array}$ & $\begin{array}{l}1395.700 * * * \\
(6.407)\end{array}$ & $\begin{array}{l}1573.600 * * * \\
(4.837)\end{array}$ \\
\hline$T_{B C}$ & $\begin{array}{l}118.220 * \\
(1.682)\end{array}$ & $\begin{array}{l}349.840 * * \\
(2.185)\end{array}$ & $\begin{array}{l}114.090 \\
(0.791)\end{array}$ & $\begin{array}{l}10.152 \\
(0.421)\end{array}$ & $\begin{array}{l}127.200 * \\
(1.855)\end{array}$ & $\begin{array}{l}-203.557 * * \\
(-1.988)\end{array}$ \\
\hline$T_{B C}^{2}$ & $\begin{array}{l}-10.913^{*} \\
(-1.823)\end{array}$ & $\begin{array}{l}-30.915^{* *} \\
(-2.266)\end{array}$ & $\begin{array}{l}-5.410 \\
(-0.440)\end{array}$ & $\begin{array}{l}-0.435 \\
(-0.212)\end{array}$ & $\begin{array}{l}-9.723^{*} \\
(-1.664)\end{array}$ & $\begin{array}{l}21.110 * * \\
(2.420)\end{array}$ \\
\hline$T_{B C}^{3}$ & $\begin{array}{l}0.305 * * \\
(2.088)\end{array}$ & $\begin{array}{l}0.806 * * \\
(2.425)\end{array}$ & $\begin{array}{l}0.084 \\
(0.284)\end{array}$ & $\begin{array}{l}0.015 \\
(0.313)\end{array}$ & $\begin{array}{l}0.233 * \\
(1.673)\end{array}$ & $\begin{array}{l}0.493 * * \\
(-2.319)\end{array}$ \\
\hline $\begin{array}{l}\text { System } R^{2} \\
\text { Sample Size }\end{array}$ & $\begin{array}{l}0.971 \\
130\end{array}$ & $\begin{array}{l}0.886 \\
130\end{array}$ & $\begin{array}{l}0.994 \\
130\end{array}$ & $\begin{array}{l}0.978 \\
130\end{array}$ & $\begin{array}{l}0.957 \\
130\end{array}$ & 0.888 \\
\hline $\begin{array}{l}\text { Sample Size } \\
\text { Lik. Rat.-test }\end{array}$ & 130 & 130 & 130 & 130 & 130 & 130 \\
\hline (Corr. Errors): & $72.527 * * *$ & $187.400 * * *$ & $154.08 * * *$ & $69.858 * * *$ & $97.308 * * *$ & $49.106 * * *$ \\
\hline
\end{tabular}

a $C O N S T=$ constant; $T=$ time coefficient $A T L=$ Atlantic region; $Q U E=$ Quebec; $O N T=$ Ontario; $P R A=$ Prairie region; $B C=$ British Columbia.

$\mathrm{b}$ Values in parenthesis are $t$-statistics, and ***,**, and * represent significance levels at the $0.01,0.05$, and 0.10 levels of significance. 
As mentioned previously, if variable costs surpass valueadded production, there will be negative profits in the industry. While it may be feasible for a firm to endure short-run losses, there must be foreseeable profits in the future; otherwise a firm will be forced out of business. When inspecting Table 1, it is obvious that most regions experienced a "profits squeeze" in the early 1980s and again (however less so) in the early 1990s, which corresponds to the Canadian economic recessions that also occurred at these times. Here, the paper \& allied sector tended to be the hardest hit, where negative profits were observed in the early 1980s for most regions. It may not be a coincidence that governments became active in supporting further value-added production during this time. Indeed, their efforts may have been necessary to insulate the industry against such negative market shocks.

Overall, there has been a general increase in real value-added when comparing the 1975-79 period with the 1990-94 period for all regional forest sectors. Growth rates range from a high of $+153 \%$ in the Prairie paper $\&$ allied sector to a low of $0 \%$ in the Ontario logging sector. Most sectors range at the 10-50\% level. However, associated with the increase in value-added growth, is an observed real growth in variable costs for most wood product and paper \& allied sectors (the exception being the Atlantic region's paper \& allied sector). While the growth in the wood sector's variable costs have been lower than that of value-added, the opposite is true for most paper \& allied sectors. Specifically, variable cost growth has outpaced value-added growth in the Quebec, Ontario, Prairie, and British Columbia paper \& allied sectors. The logging sector, on the other hand, has seen a general decline in variable costs, which together with the increasing value-added value indicates that this sector is making more total profit. However, before making such assertions, a more in-depth analysis must be performed on the data to reveal whether these trends are statistically significant.

\section{Results}

The SUR coefficient estimates for the logging, wood, and paper $\&$ allied sectors are reported in Table 2 for value-added and variable cost systems. For all regressions where any of the time trend variables $\left(T, T^{2}, T^{3}\right)$ are individually significant, the $\chi^{2}$-test rejects the null hypothesis that they are jointly insignificant (not shown in Table 1 for space considerations). Additionally, when all of the cubic time trend variables are found to be individually insignificant, the $\chi^{2}$-test does not typically reject the null hypothesis that they are jointly insignificant. ${ }^{9}$ Additional tests indicate that the data are generally free of heteroscedastic and autocorrelation biases.

The system $R^{2}$ values range from a high of $99.4 \%$ to a low of $88.6 \%$. This indicates that a high amount of the variability of value-added and variable costs is explained by the cubic time function. However, Berndt (1991) has indicated that the SUR system $R^{2}$ value should be interpreted with caution. Focusing instead on the individual-equation $R^{2}$ values that are also reported under the SUR method, findings indicate a much wider array of values. Specifically, the individual equation $R^{2}$ values range from a high of $85.9 \%$ in the Prairie

\footnotetext{
9 The exceptions include the value-added sectors in the Atlantic region, the value-added wood and paper $\&$ allied sectors in Ontario, the variable cost logging and wood sectors in the Atlantic region, the variable cost sectors in Ontario, and the variable cost logging sector in the Prairie region and British Columbia.
}

value-added logging sector to a low of $8 \%$ in the Quebec variable cost logging sector (again not shown in Table 1 for space considerations). Overall, the individual-equation $R^{2}$ values are generally smaller in the logging sector relative to the wood and paper $\&$ allied sectors.

For all regional forest sectors in Canada, the regression results indicate non-declining long-run trends in real value-added over the $1970-95$ period (see Fig. 1 to 3 ). ${ }^{10}$ Specifically, a number of regional sectors have experienced a horizontal trend over the sample period. This is true of the Atlantic region, Quebec, and Ontario logging sectors, the Atlantic region and Ontario wood sectors, and the Atlantic and Ontario paper \& allied sectors. All other sectors, with the exception of Quebec's paper $\&$ allied sector, have experienced an inverted sideways-S shaped trend. In Quebec's paper \& allied sector, a monotonic trend has occurred.

From the modeled trends it is observed that British Columbia has produced a large and growing share of valueadded in the Canadian logging sector, although the Prairie region has recently been taking on even higher proportional growth A similar circumstance has occurred in the wood sector. Lastly, Quebec has become the largest value-added producer in the paper \& allied sector; however, again the Prairie region has been taking on even higher proportional growth.

Real variable cost trend results are quite different from that of value-added, as seen in Fig. 1 to 3 . For instance, the provinces that have experienced horizontal variable cost trends include all regional logging sectors, the Atlantic region and Ontario wood product sectors, and the Ontario paper \& allied sector. All other sectors have experienced an inverted sideways-S shaped trend.

Together, the real value-added and variable cost trends indicate a number of important findings with regards to total profit (VA minus VC) and future value-added growth trajectories. Firstly, a number of sectors have been consistent in generating positive total profit, but are not growing (in terms of value-added). This is true of the logging sector in the Atlantic region, Quebec, and Ontario, the wood sector in the Atlantic region and Ontario, and the paper \& allied sector in Ontario. Secondly, a few sectors have experienced variable (positive and negative) total profits in the past but are showing recent tendencies toward achieving positive profits. These include the paper \& allied sector in the Atlantic region, the Prairie region, and British Columbia. Lastly, a number of sectors have been consistent in generating positive total profit and are tending to increase profit and growth. These include the logging sector in the Prairie region and British Columbia, the wood sector in Quebec, the Prairie region, and British Columbia, and the paper \& allied sector in Quebec.

The results of this study point to very different time-paths of value-added and variable cost variables when compared with the results of Meil (1990). Specifically, Meil (1990) found declining variable trends in British Columbia's, Ontario's, and Quebec's lumber sectors. In the current study, the lumber sector is included in, and constitutes the largest component of, the

\footnotetext{
10 The trends in Fig. 1 to 3 have been constructed by plotting the point estimates of the model, shown in Table 2, using the significant coefficients (at the $90 \%$ level of confidence or above). For instance, a horizontal trend results if no time coefficients are significant. Alternatively, an inverted sideways S-shaped curve results if all three time coefficients are significant (and the first, second, and third time coefficients are positive, negative, and positive, respectively).
} 


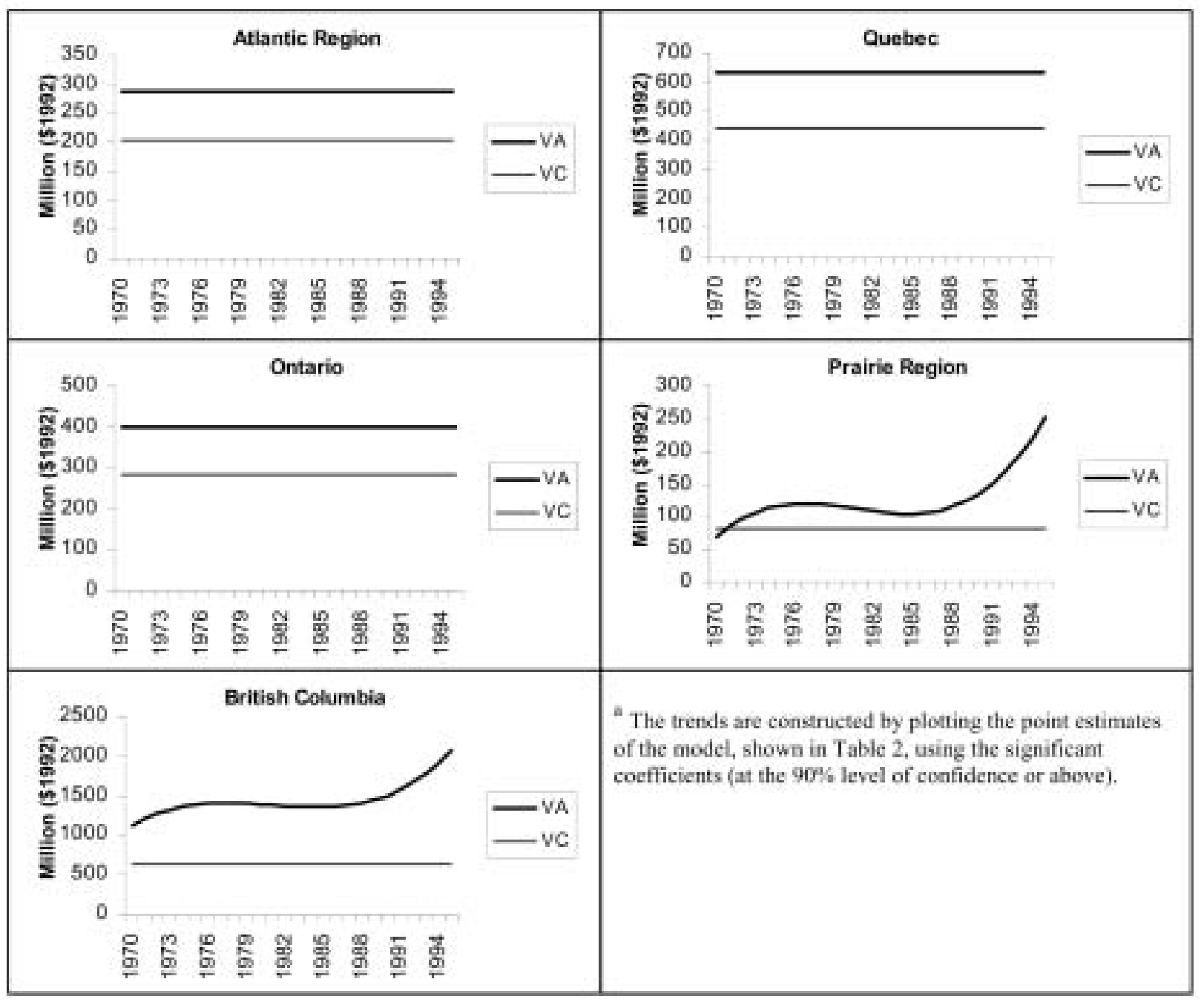

Fig. 1. Regional value-added (VA) and variable cost (VC) trends in the Canadian logging sector. ${ }^{\mathrm{a}}$

wood sector. Thus, although a direct comparison is not possible, it can be said with some degree of confidence, that the negative trends found by Meil (1990) in the 1970-84 period have, in most cases, been reversed (the only exception includes Ontario, where the wood sector trend is now horizontal). This reversal coincides with the aforementioned studies that have documented increases in efficiency, productivity, and overall competitiveness in the Canadian forest industry. In all, given the historical trends found in this study, the future looks bright for many sectors in this industry. However, one must be cautious when predicting the future from past trends. This issue is summarized in the concluding section below.

\section{Summary and Conclusion}

This study has examined the value-added and variable cost trends in five regions and three sectors of the Canadian forest industry over the 1970-95 period, and has uncovered some interesting findings. First, there is considerable variation in value-added, variable cost, and total profit trends in all regions and sectors of the industry. Some have exhibited consistent levels of value-added production, while others have exhibited long-run increasing trajectories. In many cases variable costs are beginning to trend away from value-added; however, some of the paper $\&$ allied regions are recovering from a profits squeeze in the mid 1990s. These positive findings are likely a result of the value-added and technology adoption strategies introduced and facilitated in the early 1980s. Specifically, previous strategies to improve resource quality (Barbour and Kellogg 1990), diversify and expand export markets (Cohen 1992), encourage more creativity (Baldwin 1998), and facilitate modernization/R\&D investments through government policies (Shaw 1994, ACOA 1998) have together set the stage for the observed increases in total profits for many sectors of this industry.

The particular regions and sectors of the Canadian forest industry that have shown favourable long-run value-added and 


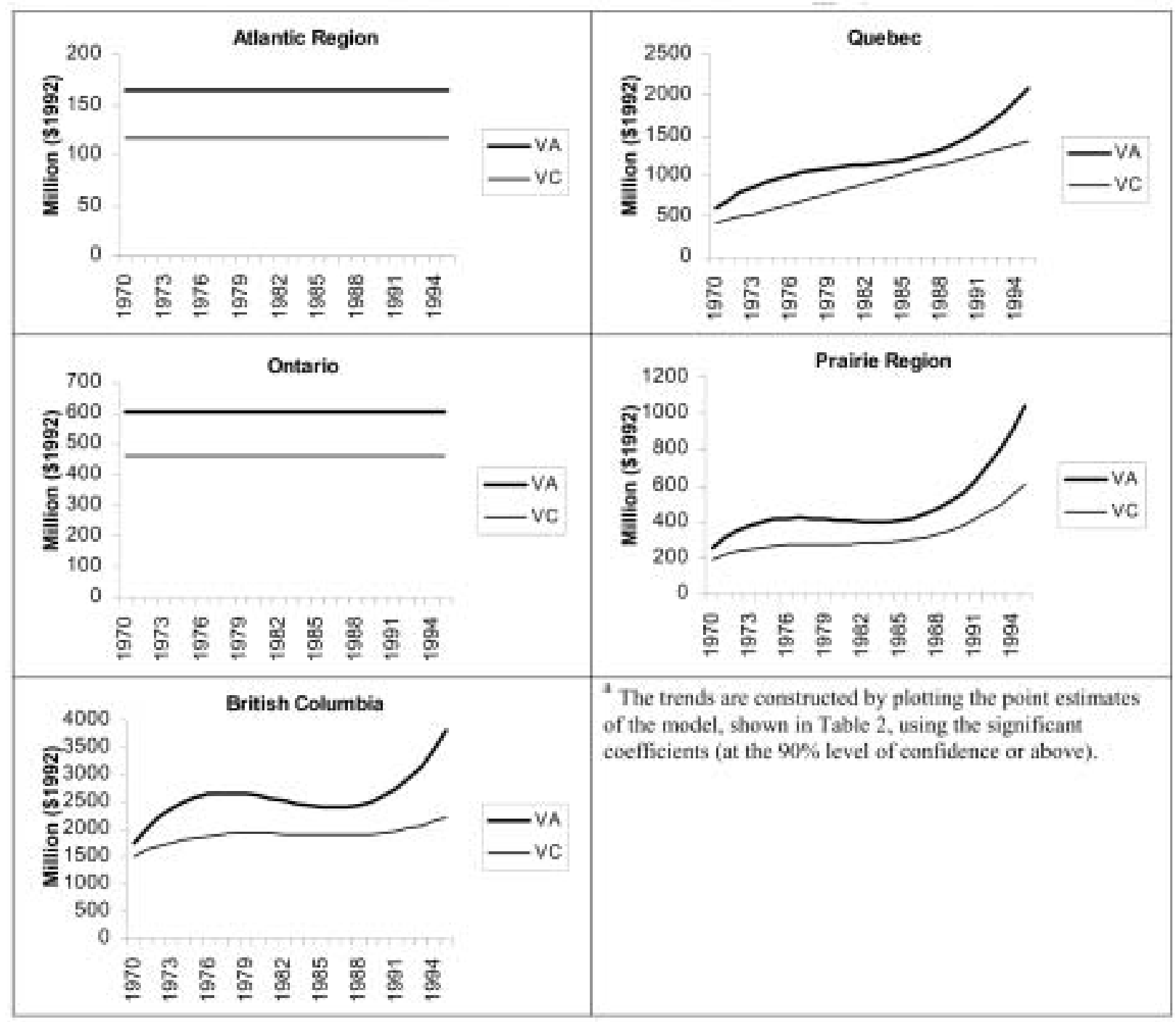

Fig. 2. Regional value-added (VA) and variable cost (VC) trends in the Canadian wood sector. ${ }^{\text {a }}$

variable cost trends include: (i) the logging sector in the Prairie region and British Columbia; (ii) the wood sector in Quebec, the Prairie region, and British Columbia; (iii) and the paper $\&$ allied sector in Quebec. Based on these trends, it is likely that future investments in these sectors and regions will provide the greatest benefit in the immediate future.

Some regional paper \& allied sectors, however, have experienced negative total profits in the past but are showing tendencies toward achieving positive profits. These regions, including the Atlantic region, the Prairie region, and British Columbia, are in the process of transitioning through depressed pulp prices and industrial restructuring. Although the trends point to positive total profits in the future for these paper $\&$ allied regions, government policies might be directed here to aid in the development.

Additionally, as Lantz (In Press) suggests, continued investments that: (i) increase the operational scale of each regional forest sector; (ii) increase the network scale of the logging and pulp \& paper sector; and (iii) increase the rate of technological innovations in order to offset the negative effect of increasing fibre quality constraints, are likely to be highly successful in increasing value-added.

The realization of sustained long-run value-added growth in forest industry sectors will, however, require favourable market forces in the future. The extent to which this will occur is uncertain. For instance, the increasingly strict environmental regulations that have occurred since the late 1980s may tend to increase harvesting costs in the future (Sedjo 1997), and thereby directly limit value-added in the logging sector. Additionally, as the global supply of pulp increases from the new supplies in Latin American and South East Asian plantations, pulp prices may continue their downward trends (Alavalapati et al. 1990), and thus limit value-added in the paper \& allied sector. Moreover, the recent increases in energy prices may have a depressing impact on value-added production in energy-intensive forest sub-sectors such as pulp \& paper. 


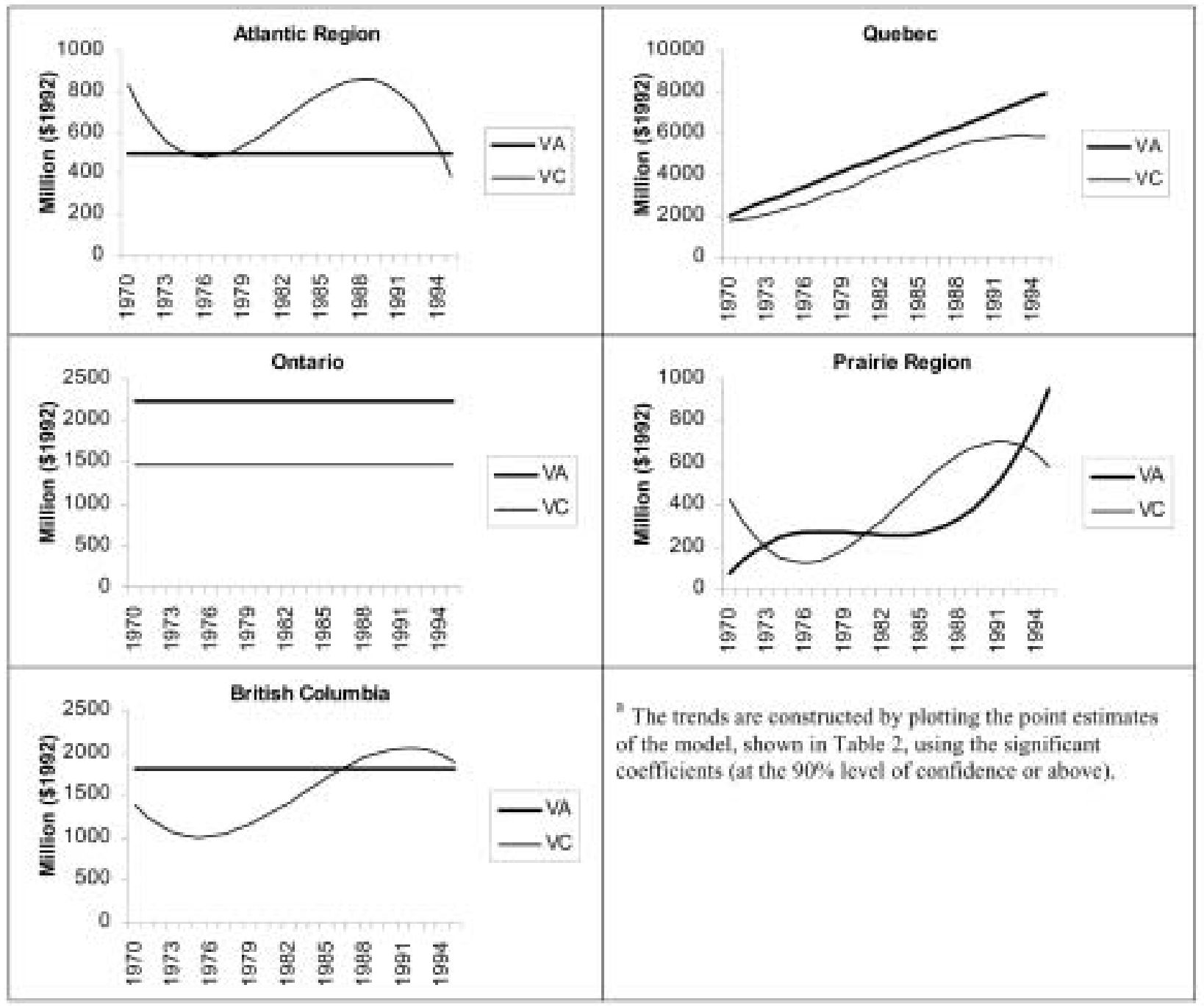

Fig. 3. Regional value-added (VA) and variable cost (VC) trends in the Canadian paper \& allied sector. ${ }^{a}$

Other factors, such as currency appreciation, tariffs, lagging technological innovations, and labour disputes are all factors that could mitigate value-added growth initiatives in this industry. Further research is needed in forecasting these elements in the Canadian context, linking them with value-added growth, and determining policies that will best suit the industry in the future.

\section{Acknowledgements}

I wish to thank two anonymous referees at The Forestry Chronicle for their helpful comments while retaining responsibility for any remaining errors.

\section{References}

Abt, R., B. Brunet and D. Roberts. 1994. Productivity growth and price trends in the North American saw milling industries: an interregional comparison. Can. J. For. Res. 24(1) 139-148.

ACOA. 1998. The Wood Industry in Atlantic Canada: a Focus on Valueadded. Atlantic Canada Opportunities Agency, Fredericton.
Alavalapati, J.R., W.A. White and M. Patriquin. 1999. Economic impacts of changes in the forestry sector: a case study of the Foothills region in Alberta. For. Chron. 75(1): 121-127.

Baldwin, R. 1998. To add value, you must first use your head. Wood Technology 125(6): 41-45.

Barbour, R. and R. Kellogg. 1990. Forest management and end-product quality: a Canadian perspective. Can. J. For. Res. 20: 405-414.

Berndt, E. 1991. The Practice of Economics. Addison-Wesley, UK. Bernstein, J. 1994. Exports, margins, and productivity growth: with an application to the Canadian softwood lumber industry. Review of Economics and Statistics 76(2): 291-301.

Brunet, J. 1993. Productivity in Canada's pulp and paper industry: an inter-regional comparison. Working Paper. Policy and Economics Directorate, Forestry Canada, Ottawa.

Cohen, D. 1992. Adding value incrementally: a strategy to enhance solid wood exports to Japan. Forest Products Journal 42(2): 40-44. Duke, J. and C. Huffstutler. 1977. Productivity in sawmills increases as labour input declines substantially. Monthly Labour Review 10(4): 33-37. 
Frank, D., A. Ghebremichael, T. Oum and M. Tretheway. 1990. Productivity performance of the Canadian pulp and paper industry. Can. J. For. Res. 20(6): 825-836.

Ghebremichael, A., D. Roberts and M. Tretheway, M. 1990. Productivity in the Canadian Lumber industry: an inter-regional comparison. Forestry Canada Information Report 0-411. 73 p.

Greene, W., 1993. Econometric Analysis, second ed. Prentice Hall, Englewood Cliffs, NY.

Hailu, A. and T. Veeman. 2003. Comparative analysis of efficiency and productivity growth in Canadian regional boreal logging industries. Can. J. For. Res. 33: 1653-1660.

Hseu, J. and J. Buongiorno. 1994. Productivity in the pulp and paper industries of the U.S. and Canada: a nonparametric analysis. Can. J. For. Res. 24(12): 2353-2361.

Kant, S. and J. Nautiyal. 1997. Production structure, factor substitution, technical change, and total factor productivity in the Canadian logging industry. Can. J. For. Res. 27(5): 701-710.

Lantz, V. 1995. Elasticities of scale in the Canadian forest industry: A regional/sectoral approach (1974-93). Dalhousie University, Halifax, Nova Scotia.

Lantz, V. In Press. Measuring scale, technology and price effects on value-added production across Canadian forest industry sectors Forest Policy and Economics. 13 p.
Meil, J. 1990. Value-added trends and technology feasibility limits in Canadian Softwood Lumber Producing Regions. For. Chron. 66(1): 45-50.

Meil, J. and J. Nautiyal. 1988. An intraregional economic analysis of production structure and factor demand in major Canadian softwood lumber producing regions. Can. J. For. Res. 18: 1036-1048.

NRCan. 2004. Selected forestry statistics Canada. Natural Resources Canada. Available at: http://mmsd1.mms.NRCan.gc.ca/forest/default_e.asp Schuler, A. and J. Meil. 1990. Markets, products and technology in the $21^{\text {st }}$ century: a Canadian solid wood products perspective. For. Chron. 66(6): 567-571.

Sedjo, R. 1997. The forest sector: important innovations. Discussion Paper 97-42. Resources for the Future, Washington, DC.

Shaw, D. 1994. The forest industries R\&D and innovation program. Pulp and Paper Canada 95(5): 215-219.

Statistics Canada. 1970-95. Canadian Forestry Statistics. Statistics Canada, Ottawa, Catalogue No. 202-25.

Statistics Canada. 2001. CANSIM. Statistics Canada, Ottawa Available at: http://cansim.epas.utoronto.ca:5680/cansim/search.html. Wilson, B., B. Stennes and S. Wang. 1999. An examination of secondary manufacturing in British Columbia: structure, significance, and trends. Working Paper 99.02. Natural Resources Canada, Canadian Forest Service, Pacific Forestry Centre, Victoria, B.C. 34 p. 